Forensic long-stay in Europe

Long-term forensic mental health services: an exploratory comparison of 18 European countries

Authors

Stephanie Sampson (Lead author)

PhD Student/Research Assistant

Institute of Mental Health, University of Nottingham Innovation Park, Triumph Road, Nottingham

United Kingdom, NG7 2TU

stephanie.sampson@nottingham.ac.uk

Rachel Edworthy

Research Assistant

School of Medicine Division of Psychiatry and Applied Psychology, Section of Forensic Mental Health Institute of Mental Health, University of Nottingham Innovation Park, Triumph Road, Nottingham United Kingdom, NG7 2TU

rachel.edworthy@nottingham.ac.uk

Dr Birgit Völlm (Corresponding author)

Professor in Forensic Psychiatry, Head of Section Forensic Mental Health

School of Medicine Division of Psychiatry and Applied Psychology, Institute of Mental Health

University of Nottingham Innovation Park, Triumph Road, Nottingham

United Kingdom, NG7 2TU

birgit.vollm@nottingham.ac.uk

Dr Erik Bulten

Head of Assessment, Research and Professional Development

Pompefoundation, Pro Persona, Weg door Jonkerbos 55

Nijmegen, NL

e.bulten@pompestichting.nl 


\begin{abstract}
The objective of this study was to explore current provisions within forensic mental health inpatient services for people who require longer-term care within Europe. We used a structured questionnaire and follow-up semi-structured interviews with experts in forensic psychiatry in 18 European countries. All experts interviewed acknowledged the issue of 'longstay' in forensic psychiatry with patient characteristics including chronic mental disorder, treatment-resistance and violent behaviour. Formal and informal definitions of 'long-stay' varied widely between countries. Eight experts stated that long-stay services are currently available in their country, either in a separate hospital or specific treatment wards. Of the countries without long-stay services, five experts expressed a need develop them. Improved quality of life and promotion of wellbeing were emphasised as the fundamental treatment philosophy. Even without an agreed definition of 'long-stay', it is clear that a proportion of mentally disordered offenders (MDOs) are 'stuck' in 'the system'. Experts shared common concerns in terms of political pressures to contain dangerous MDOs for ensuring public safety as well as ethical debates regarding long-term forensic mental health care. Further research is required to promote dialogue between and within countries to address the balance of patients' rights and public safety, and to produce longitudinal and economic analyses of existing long-stay forensic service provisions.
\end{abstract}

Key words: forensic psychiatry; mentally disordered offenders; long-stay services; European comparison.

\title{
Introduction
}

\section{Scope of the Problem}




\section{Forensic long-stay in Europe}

The appropriate care and risk management of mentally disordered offenders (MDOs) poses a number of complex treatment, moral and ethical challenges (Boyd-Caine, 2012; Buchanan \& Grounds, 2011; Konrad \& Völlm, 2010; Mullen, 2000). Though a rapid reduction of beds in psychiatric hospitals generally has been witnessed internationally, there has been a significant increase in demand for forensic services (Hodgins, Müller-Isberner, \& Allaire, 2006; JansmanHart, Seto, Crocker, Nicholls, \& Cote, 2011; Priebe et al., 2005, 2008). While the length of stay (LoS) in forensic inpatient mental health services has fallen, at least in some countries, and recovery principles have been applied to MDOs (Sugarman \& Oakley, 2012), a number of patients still experience lengthy stays in forensic services, potentially at inappropriately high levels of security (Shah, Waldron, Boast, Coid, \& Ullrich, 2011; Sharma, Dunn, O’Toole, \& Kennedy, 2015; Shaw, Davies, \& Morey, 2001). This is of concern for two reasons; firstly, lowvolume inpatient forensic services are cost and resource intensive, and secondly, the quality of life in these restrictive environments may be poor (Joint Commissioning Panel for Mental Health, 2013; Vorstenbosch, Bouman, Braun, \& Bulten, 2014). Data from a previous comprehensive European comparison highlights the wide variation across Europe regarding total numbers of forensic cases (ranging from 100 in Ireland to 5,400 in Germany in 2002) and prevalence rates per 100,000 population (ranging from two in Greece to 21.7 in Denmark (Salize \& Dressing, 2005)). Costs are also high, with a general increase in LoS in medium to high secure hospitals in England and Wales (Rutherford \& Duggan, 2007) and an average per person cost of $£ 200,000$ in medium secure settings per year (Walker, Craissati, Batson, Amos, \& Knowles, 2012).

\section{Factors Associated with Length of Stay}




\section{Forensic long-stay in Europe}

There is currently no generally accepted definition of 'long-stay' in forensic settings, and little is known about the LoS of these patients in different countries. In England, research has found an average LoS in high secure care of eight years (Dell, Robertson, \& Parker, 1987), and for medium secure care it is a little over two years (Edwards, Steed, \& Murray, 2002). However, some authors have described a trend for patients to stay for five years or more (Rutherford \& Duggan, 2007; Shah et al., 2011; Jacques, Spencer, \& Gilluley, 2010) with around a third of medium secure patients deemed to need long-term care (Melzer et al., 2004). A more recent cross-sectional study identified that around $16 \%$ of patients resident in high secure settings in England had been resident for more than 10 years, and around 3\% for more than 20 years (Völlm, 2015). The Netherlands and Germany have also experienced increasing lengths of stay in forensic inpatient mental health services and increasing numbers of patients in need of longer-term care (Giesler, 2012; Nagtegaal, van der Host, \& Schonberger, 2011).

Some previous research has been directed towards identifying characteristics of patients who stay in forensic inpatient mental health services for excessive time periods (Alderman, 2001; Long et al., 2010; Wheatley, Waine, Spence, \& Hollin, 2004; Yorston, 1999). Based on discharge samples, comparing those with longer versus shorter lengths of stay, severity of index offence was identified as most important in personality disordered, and psychopathology in patients with mental illness in UK high secure settings (Dell et al., 1987). In UK medium secure settings, research has identified severity of psychopathology, psychiatric history, seriousness of offending, being on a restriction order (requiring Ministry of Justice permission for transfer and discharge), non-engagement in interventions, dependency needs and lack of step-down facilities associated with longer stay populations (Brown \& Fahy, 2009; Jacques et al., 2010; Kennedy, Wilson, \& Cope, 1995; Long \& Dolley, 


\section{Forensic long-stay in Europe}

2012; McKenna, 1996; Shah et al., 2011). Recent research in Sweden of a high-risk forensic cohort has highlighted that violent index criminality, among other factors, is an important factor associated with longer stays in forensic psychiatric treatment (Andreasson et al., 2014). Research has also highlighted severity of the offences committed (Baldwin, Menditto, Beck, \& Smith, 1992; Green \& Baglioni, 1998), neuropsychological impairment and low IQ as factors associated with LoS (Colwell \& Colwell, 2011). Research from the USA has highlighted problematic behaviour and increasing physical health problems associated with long-stay (Fisher et al., 2001), and research from Ireland associated severe mental illness and violent offending with increased LoS (O'Neill et al., 2003). However, little is known about the patient characteristics of those who remain in secure care, how to formally identify them, or how to best meet their needs in existing services when they may require longer-term care than other patients. There exists a patient population who, due to a perceived long-term risk, spend their entire lives in secure forensic settings. As such the question needs to be asked whether this population's needs are currently being catered for in mixed populations (that is, with 'shorterterm' patients leaving the system quicker, but who may be more acutely unwell than the longterm patient population). With some individuals spending their entire lives in secure settings, restrictions on personal freedoms become more apparent, including restrictions on patients' rights to family life and sexual expression. For example, Tiwana and colleagues (2016) found that many countries lack national policies on sexual expression for patients in forensic mental health services, with the UK in particular being most prohibiting. For people subject to such restrictive settings, it is relevant to explore whether designated long-stay services are able to address fundamental rights and needs of this patient population.

\section{International Perspective}




\section{Forensic long-stay in Europe}

At the international level, complex differences in patient populations, diagnoses, legal frameworks, differing concepts of criminal responsibility, service provision as well as cultural, political and public expectations lead to heterogeneity in MDOs admitted to forensic care and mental health services providing this care (Edworthy, Sampson, Völlm, 2016; Salize \& Dressing, 2005). Such differences impact on service provision and treatment outcomes for individuals; for example, certain countries provide various forensic inpatient and outpatient mental health services, while others either do not recognise forensic psychiatry as a separate specialty, or do not possess the sufficient resources or training in order to ensure satisfactory service provision for MDOs (Salize and Dressing, 2005). Some countries have developed policies and services specifically designed for long-stay patients and it is this service provision that is the focus of exploration in our study.

\section{Objective of Current Study}

This study sought to explore current service provisions within forensic mental health inpatient services for those who require longer-term care within Europe. In order to put provision for this patient group in context, we also describe briefly the legal framework governing forensic mental health services in each country, as well as availability and access to services for MDOs. We then investigate the availability of long-stay services in 18 countries within Europe, with a focus on definitions of long-stay, legal frameworks, service configuration, patient populations, quality of life and ethical issues.

\section{Methods}

\section{Context}




\section{Forensic long-stay in Europe}

All but three included countries are members of the European Union (the exceptions being Switzerland, FYR Macedonia and Serbia), and all countries in this study are state parties to the European Convention on Human Rights and Fundamental Freedoms (ECHR, Council of Europe, 1950), which provides a common-ground that 'legitimises international scrutiny of mental health policies and practices within a sovereign country' (Salize \& Dressing, 2005). Furthermore, all included countries, as of 2015, have signed and ratified the European Convention for the Prevention of Torture and Inhuman or Degrading Treatment or Punishment (CPT, Council of Europe, 1987) with most also ratifying the Convention on the Rights of the Persons with Disabilities (CRPD, United Nations, 2006; Finland, Ireland and The Netherlands are all signatories but have yet to ratify the CRPD). Each of these conventions place responsibilities and obligations on state parties to ensure and promote certain human rights and fundamental freedoms for all people without discrimination, particularly when deprivation of liberty has been ordered by a public authority after the commission of a crime or in the context of a persons' mental disorder or other disability.

\section{Design}

We approached experts associated with the EU-funded COST action IS1302 (Cooperation in Science and Technology) 'Towards an EU research framework on Forensic psychiatric care'. ${ }^{1}$ A national selection process is required to join this network, which ensures all COST country representatives are leading clinicians and researchers with expertise in forensic psychiatry and a particular interest in long-term forensic psychiatry. A written questionnaire was developed by the core group of the COST action (grant holder, chair, co-chair, scientific advisor; see online materials). Topics addressed included system and definition elements,

\footnotetext{
${ }^{1}$ http://www.cost.eu/COST Actions/isch/Actions/IS1302; this website also lists all national experts.
} 


\section{Forensic long-stay in Europe}

admission and discharge, patient characteristics and service provisions. This questionnaire ${ }^{2}$ was designed to provide context, prepare for and direct the content and structure of the subsequent semi-structured interviews ${ }^{3}$. Semi-structured interviews were conducted by telephone with the experts that had provided the questionnaire for their country (see online materials). The interviews focused on service provision for long-stay populations in each country, characteristics and practice of service provision, key challenges and hindrances in their implementation and outcomes. Information about practical aspects of such services (e.g. size of wards, level of security) as well as clinical and risk factors, treatment pathways, legal frameworks, perspectives on quality of life and ethical considerations of long-stay facilities were also discussed. Interviews were recorded with consent of the participant and were subsequently transcribed and analysed using thematic qualitative analysis. All participant data were anonymized, with all names removed from within transcripts, and stored securely as per the Data Protection Act 1998. The study was part of a larger, national, multi-centre project, sponsored by Nottinghamshire Healthcare NHS Trust, which provided Research and Development (R\&D) approval. Due to the nature of the study (expert interviews) separate NHS research ethics approval was not required.

\section{Procedure}

We gathered data from 18 separate countries in total. Out of the 19 countries participating in the ISCH COST action IS1302, we were able to interview 17 representatives from 16 countries (one per country, with two from the Netherlands); ${ }^{4}$ all interviews took place via

\footnotetext{
${ }^{2}$ Countries completing the questionnaire: Belgium, Croatia, England, Finland, Germany, Ireland, Italy, Latvia, Lithuania, FYR Macedonia, Poland, Portugal, Serbia, Slovenia, Spain, The Netherlands

${ }^{3}$ Countries interviewed: Belgium, England, Finland, France, Germany, Ireland, Italy, Latvia, Lithuania, Poland, Portugal, Serbia, Slovenia, Spain, Switzerland, The Netherlands

${ }^{4}$ For the full list of ISCH COST action IS1302 participants, see:

http://www.cost.eu/COST Actions/isch/Actions/IS1302?parties. We were unable to obtain any data from Cyprus or
} 


\section{Forensic long-stay in Europe}

teleconferencing (in the English language) between June 2013 and November 2014. For the remaining two countries (Croatia and Macedonia), we were only able to use data from the initial structured questionnaire.

\section{Analysis}

Data analysis was conducted using thematic analysis (Braun \& Clarke 2006) to identify common themes, and was coded using NVivo qualitative data analysis software by one researcher, with $20 \%$ (i.e. four interviews) double-coded by the senior author (NVivo, 2014). Data were analysed both inductively (with themes that emerged from interview content) as well as deductively via the use of coding determined by the themes explored in both the initial questionnaires and subsequent semi-structured interviews (Fereday, 2006). All participants checked the full interview transcripts for accuracy of their statements before analysis.

\section{Results}

\section{Legal Frameworks and Service Provision for Mentally Disordered Offenders}

\section{Legal frameworks}

The majority of countries included in this study operate under civil law jurisdiction, with only England, Wales ${ }^{5}$ and Ireland operating under common law jurisdiction. Procedural differences between admission and diversion provisions can be partly attributed to legislative differences. In some countries, e.g. Germany and Switzerland, local variations exist in the various 'states'

\footnotetext{
Greece. Switzerland is not a party to COST, however, and was additionally recruited through the Forensic Section of the European Psychiatry Association due to the long history of forensic psychiatry in Switzerland.

There were two experts from the Netherlands as the first participants did not have a clinical role but was interviewed as having an overview of service organisation across the country as part of their role.

${ }^{5}$ The MHA 1983 and the criminal laws referred to throughout this paper apply to England and Wales, however the representative interviewed as well as the figures and comments on service provision are specific to England only.
} 


\section{Forensic long-stay in Europe}

('Länder' in Germany, 'Kantone' in Switzerland). In Germany, however, state laws define patient rights and staff duties, which vary considerably between states with no standardised procedures beyond admission and discharge of forensic patients.

The majority of countries' legal frameworks relevant to the management of MDOs are found under criminal laws and penal codes as well as dedicated mental health legislation. The seven countries in which MDOs are managed mainly via mental health legislation (i.e. separate to penal codes or criminal codes) include England and Wales (Mental Health Act 1983), Ireland (Mental Health Act 2001), Croatia (Protection of Persons with Mental Disorders 2015), Lithuania (Mental Health Care of the Republic of Lithuania 1997), Serbia (Protection of Persons with Mental Disorders 2013), Finland (Mental Health Act 1990) and Slovenia (Mental Health Act 2008). With the exception of Latvia and Macedonia, the former Soviet Socialist Republic (Lithuania) and three former Yugoslavia Republics (Croatia, Serbia and Slovenia) have designated new mental health legislation separate from criminal laws or penal codes, with the intention of more closely complying with shared international legal obligations under the ECHR, the CPT and the CRPD.

Croatia (the EU's most recent member state to join in 2013) introduced the country's law on the 'Protection of Persons with Mental Disorders', which came into effect January 2015. This new legislation intends to replace the traditional medical model approach to treatment with a human rights based approach to reflect the principles of the CRPD (Bagarić, Živković, Curković, Radić, Brečić, 2014). This is an important development in mental health law in Europe, with implications for the way in which the CRPD is acknowledged and implemented by countries that are signatories to the convention. For individuals with disabilities deprived 


\section{Forensic long-stay in Europe}

of their liberty, provision of 'reasonable accommodation' (Article 14) is of particular concern to long-stay forensic populations.

\section{Access to forensic mental health services}

Forensic mental health services and general mental health service provision for prison populations vary widely between countries (see Table 1 for an overview of services, and Table 2 for patient population characteristics, admission and discharge procedures).

Most countries included (with the exception of England and Wales, Finland and Latvia) stipulate that a treatment order/ forensic placement and a prison sentence can be imposed at the same time, with the order by which they are served differing between countries (as also detailed by Salize \& Dressing, 2005). Most countries' admission procedures allow for MDOs to be 'diverted' from the criminal justice system to forensic mental health services either before or after sentencing (Table 1).

Diversion from prison to a designated forensic or psychiatric hospital is not possible in Croatia, Germany, Italy, Lithuania, the Netherlands or Serbia; if a prison sentence is imposed and subsequently a mental disorder emerges, then treatment is provided for via prison general psychiatric services or a designated prison hospital. After diversion from prison to forensic mental health services for treatment, should treatment be considered complete, most countries require the patient to be sent back to prison to complete their sentence. Finland, Italy, Latvia, Lithuania, Poland and Portugal are the exceptions, where patients are either discharged back to the community or sent to facilities of lower security. Each country expert stated that there was no fixed release date for people admitted to forensic mental health services, with the key criterion of dangerousness as justification for lengthier stays. It is worth 


\section{Forensic long-stay in Europe}

noting, however, that since the time of the present study, new legislation has been introduced in Croatia and Italy specifying that patients cannot remain in forensic settings for longer than what would have been their sentence for the same offence had they been healthy and sent to prison. Furthermore, in the case of Portugal, for crimes punishable by imprisonment for less than eight years, length of stay in a forensic mental health service cannot exceed this time. However, should dangerousness not be found to justify continued stay in a forensic mental health facility (as reviewed every two years), then the patient must be discharged. In England and Wales, patients may either be moved back to prison (while their sentence is still active) or remain in the hospital system, depending on the needs of the individual. Each country provides some inpatient prison psychiatric services, with either designated 'prison hospitals', psychiatric wards within prison, or via visiting mental health professionals (psychiatrists or psychologists); however, these services are not standardised throughout prisons in the included countries (Table 1).

Admission criteria for forensic and/or general psychiatric inpatient services for MDOs share some similarities across countries, including that a mental disorder needs to be present in order to be admitted, e.g. psychotic disorders, personality disorders (typically associated with another mental disorder), cognitive disorders, learning disabilities and substance misuse (typically associated with another mental disorder). Substance use related disorders and personality disorder (as the sole disorder) might constitute an exclusion criterion for forensic services in some countries (Table 2).

In order to be admitted as a forensic psychiatric inpatient, the majority of countries' laws and regulations stipulate that a person needs to have committed a crime and that there was a relationship between the mental disorder and the criminal behaviour. This is not the case in 


\section{Forensic long-stay in Europe}

England, Wales or Ireland in which patients can be admitted to forensic mental health services under civil legislation if they are in need of treatment but have not committed an offence. Although MDOs in Belgium and Slovenia must have committed a crime in order to be admitted as a forensic patient, they are the only other European countries that do not require a relationship between the mental disorder and the criminal behaviour. In Germany, the seriousness of a crime (usually a violent crime) and a high risk of reoffending are requirements for admission to forensic services. In most countries, it is necessary for the offender to have diminished or absent criminal responsibility in order to be admitted to forensic inpatient services. England, Finland, Ireland, Portugal, Serbia, Slovenia and Switzerland are the exceptions to this rule. In these countries, admission is typically on the basis of the need for treatment and 'therapeutic security' (Table 2).

\section{Length of Stay}

\section{Definitions}

Seven of the 18 countries were able to offer a formal definition of 'long-stay', either under legislation, regulations or based on national health research, and thirteen countries' experts provided an informal observation of length of forensic inpatient stay in secure settings (Figure 1).

The formal definitions do not necessarily reflect what would constitute a 'long-stay' in forensic mental health services in practice in Finland, Ireland, Portugal, Spain and the Netherlands. For example, Finland's law on Social and Healthcare Service Fees (1992) defines 'long-stay' as three months of continuous institutional treatment regardless of the reason for 


\section{Forensic long-stay in Europe}

treatment (i.e. applicable to forensic psychiatry, general psychiatry and somatic treatment). Subsequently, 'as Finnish law defines long-term as being over three months practically all forensic patients are long-term' (Finland). Finland's expert stated that national data relating to inpatient forensic hospitalisations gathered by the Institute of Welfare and Health (HILMO) estimated a median LoS of forensic inpatients at nine years in 2012, and around five to six years between 2010-2012. Ireland and Spain have formal definitions of 'long-stay' for general mental health services of two or more years.

In the Netherlands, long-stay is defined as a forensic measure lasting for six years or longer (see TBS, as described below). One expert from the Netherlands observed that stays of ten years or more can be seen in designated long-stay services; however, with pressure to reduce LoS in compliance with performance indicators.

'[W] have to reduce length of stay from ten to eight years... you can expect people to stay longer than those ten years, so we have to get a filter for them...' (Netherlands, Expert B). The Netherlands was the only country where a legal definition specific to forensic services exists, and patients may be transferred to specific forensic long-stay facilities once this time has lapsed under a separate legal section.

Other countries that offer a formal definition of 'long-stay' include Lithuania, FYR Macedonia and Portugal, legally defined as a lapse of six months, treatment of more than one year, and more than three years respectively. Representatives from these countries were, however, not able to provide national research data regarding LoS in forensic populations.

Figure 1 illustrates LoS in forensic care for the 13 countries where such information was provided, ranging from four years in Italy to ten years in Belgium, England and Serbia and the 


\section{Forensic long-stay in Europe}

Netherlands. These figures include participant observations of LoS in what they described as a 'longer-stay' population in various forensic services for MDOs, including high-secure populations in England and populations in designated long-stay facilities in the Netherlands.

Generally, between four to eight years was considered 'long-stay' (at varying security levels) in eight of these countries. Some countries identified that LoS had decreased in recent years:

'The cross-sectional mean length of stay for the 94 secure beds here is about seven years. That has fallen over the last ten years from being in the region of 12-13 years.' (Ireland).

'With the new medications and new treatments we do not have many situations in which patients stay for twenty years or thirty years' (Portugal).

However, the fact that some patients do spend their entire lives (or a vast amount of it) in forensic mental health services was highlighted in some interviews:

'There are also patients who stay for actually their whole life' (Latvia).

I: What are the long-term prospects for people who don't go back to the community? R: To die in prison, something like that' (Belgium).

'Offenders who won't be discharged - it's clear they can't get out during their lifetime. So they stay till they die' (Switzerland).

\section{Dedicated forensic mental health long-stay services}

Representative experts from eight countries stated that specific services are available for long-stay forensic inpatients, either in a separate hospital or specific treatment wards (Table 3). The representative from Croatia stated in the questionnaire that specific services are currently available to forensic patients who are long-stayers; however, because it was not 


\section{Forensic long-stay in Europe}

possible to undertake an interview we were not able to obtain further information. Portugal's expert stated that services were available for long-stay patients, but upon closer questioning it emerged that these services do not differ to those for patients with shorter lengths of stays. The remaining countries currently offering some form of 'long-term' forensic inpatient mental health services include: England, France, Germany, Ireland, the Netherlands and Spain (see Table 3).

Only in the Netherlands are admission criteria for these services standardised by law nationally (under a separate TBS long-stay order: Terbeschikkingstelling, translated as 'at the discretion of the state', allocating a prison sentence followed by a psychiatric treatment order for mentally disordered offenders. The prison sentence serves as punishment, followed by a treatment order to promote reduction in risk of further offending). After having been an inpatient at two separate forensic mental health hospitals for six years or more, where a patient has completed relevant treatment programmes but with little discernible progress and no foreseeable reduction in risk from further treatment, they can then be transferred to a long-stay facility following review by an independent national panel. Where other countries, such as England, France, Germany, Ireland and Spain, have specified treatment wards within forensic mental health hospitals, there are no national laws or policies to govern these and so the design of such services is left to individual units resulting in inconsistencies. The expert from Ireland provided a detailed definition of forensic long-stay, namely having been under forensic care for at least five years but with no recovery pathway to the community in the foreseeable future. In Portugal, 'long-stay' is understood as 'forensic patients in inpatient safety measures for an indefinite time'. Patient characteristics in long-stay services were described by experts as displaying violent or dangerous behaviour, 'therapeutic non- 


\section{Forensic long-stay in Europe}

responders' (or treatment-resistance), those who present a 'danger to society' (having committed violent crimes or presenting with continued violent behaviour) and those who are in the service for longer than average or 'indefinitely' (Portugal). Treatment within these facilities includes general psychiatric and medical treatment, however, with less focus towards risk reduction and greater focus on 'wellbeing' (Germany), 'quality of life' (England, Ireland and the Netherlands) or preparation for intensive rehabilitation and educational interventions (Spain).

There is greater emphasis on 'maintenance' and improving standards of living for chronic, treatment-resistant patients who present a continued risk to society, in what would otherwise be a highly restrictive environment,.

$\therefore$...[W]e are doing everything we can to prevent institutionalisation to keep their minds stimulated... essentially to maintain a decent quality of life' (Ireland).

In a long-stay facility... they get [the] regular psychiatric or medical treatments they need, but not to reduce their risk... it makes no sense to keep these patients in very expensive forensic services where they are supposed to get treatment [if] they don't respond to treatment or do not engage in treatment' (Netherlands, Expert A).

The expert in England acknowledged that different services are available to different patient groups, with 'low stimulus', 'homely environments' for treatment-resistant populations and a 'recovery-focused' pathway for low-secure, complex-diagnosis populations (with the latter identified as being effective in terms of discharge rates).

\section{Quality of life}




\section{Forensic long-stay in Europe}

The importance of addressing quality of life in service provision and care was generally recognised by all participants.

'... [W] have absolutely no other rehabilitation plans except to uphold the quality of life of this person, that's all we can do' [Finland].

'When you finally say, okay, listen we don't know how to get you out of the service [or how] to significantly reduce your risk of reoffending, so you have to stay here... what can we do to improve your quality of life?' (Germany).

In the countries that offer specialised long-term forensic mental health services, a common theme of quality of life was difficult to measure amongst patients.

'...[Y]ou ask this patient on Monday morning his opinion about his quality of life [and at the end of the day it changes]' (the Netherlands, Expert A).

'For some service users, particularly longer stay and longer-term, they have very limited capacity to give you an opinion of what they see as their quality of life' (England).

Difficulty in ascertaining patient-rated quality of life has led to uncertainty amongst practitioners as to how to achieve an improved standard for long-stay populations.

'...[W]hat was much more useful, in a structured way, was to assess what we deemed their needs as being. And if we deemed what their needs were through the Camberwell assessment of needs... then we have to provide an environment where those needs can be met.' (England). 


\section{Forensic long-stay in Europe}

Experts from the Netherlands detailed a study regarding comparisons of self-reported quality of life and proxy assessments in the Netherlands (Schel, Bouman, \& Bulten, 2015). This research compared quality of life ratings of long-stay forensic inpatients with the ratings of psychiatric nurses, who predicted patients' responses. It was found that there was poor agreement between the patient scores and the nurse's proxy scores, indicating maybe that more staff training on quality of life issues will be beneficial in supporting and optimising patient's quality of life experiences.

In countries without long-stay forensic services, quality of life was not regarded as high within prison or other mental health inpatient services for long-term populations, with lack of financing and uncertainty in meeting patients' needs as potential barriers to improvement.

'[Q] uality of life for the patients is very, very low ... [a]ctual forensic hospitals are really prisons... and prison does not make [for] easy therapeutic treatment' (Italy).

'...[T]he quality of life is bad - they have nothing to do on the psychiatric wards, no hobbies, no friends, I don't know, no family - what more can I say' (Poland, Expert A).

The experts in Serbia and Slovenia detailed lengthy travelling distance to centralised inpatient services as having a potential impact on a patient's quality of life, in terms of family visits and its impact on treatment. This highlights how it is not only the material conditions within longstay services that may influence the complex issue of quality of life, but also external factors, including physical distance from family members. Quality of life factors were considered by all experts and remain a conscious focus in improving the quality of care for long-stay populations, where there is current uncertainty as to how to improve care and living conditions if treatment progression is not made. 


\section{Forensic long-stay in Europe}

\section{Challenges in the development of long-stay services}

Long-stay services in Hessen (Germany) appear to have developed gradually over the past twenty years with little organisational or legal resistance. Some obstacles, however, were noted in the development of these designated long-stay services; difficult to manage and treat patient populations were simply secured in long-stay facilities (including those with personality disorders), which led to patient challenges regarding their right to treatment due to little prospect of recovery or release.

Experts in the Netherlands described difficulties in a lack of prescribed criteria regarding admission and discharge of patients when establishing long-stay services, an issue which is still being clarified.

In the countries without separate, designated long-stay facilities, according to experts interviewed (England, France, Ireland and Portugal), the term 'long-stay' is not a widely used concept amongst practitioners, nor is it always considered a helpful categorisation. Opinions regarding the further development of specific long-stay services were mixed, with ideological and cost-related factors impeding further development.

'I think if I was [a] commissioner l'd be a bit worried about [developing long-stay services] because, you know, obviously commissioners want as short a stay as possible in secure care because the cost is so high' (England).

'[T]he general consensus is that the psychiatrists are unhappy with the long-stay proposal... the right wing is strongly in favour, the left wing is strongly against... but if it's regularly checked [then] I think we need one' (France). 


\section{Forensic long-stay in Europe}

'...[T]he idea that anybody with a mental illness has a long-term need isn't acknowledged. This isn't just a forensic problem but it's an ideological non-scientific view that nobody with a mental illness... will not recover to complete autonomy in complete independence.' (Ireland).

:... C] ]urrently we are trying to deal with lack of funding to provide very basic health services in prisons.' (Portugal).

In the aim of reducing costs, one expert from the Netherlands contested whether long-stay facilities in fact reduced costs in the long-term.

'... [T]he fact is, because these people are older they actually need more care, they need different care than the... regular TBS patients, they need more somatic care, they need more nursing... so I'm not sure that these facilities are really cheaper' (the Netherlands, Expert A).

\section{Countries with no Long-Term Services}

For the remaining countries in which long-stay services for forensic inpatients have not been implemented, three offer a definition of 'long-stay' (Table 4). These definitions, however, apply to all patients receiving healthcare and as such are not limited to forensic mental health services.

Most country's experts stated that there has been an increase in focus on LoS in recent years and most experts observed a typical 'long-stay' of between four to ten years, with care needs not necessarily being met for these typically chronic, treatment-resistant, violent populations. Experts from Poland and Lithuania highlighted that increased LoS is not a typical problem within their forensic mental health care systems, with both country's experts indicating that 


\section{Forensic long-stay in Europe}

efforts are currently underway to create a database for the monitoring of patient characteristics and LoS.

The five countries that expressed a need for long-stay service provisions include Belgium, Latvia, Serbia, Slovenia and Switzerland; only the expert from Slovenia was able to confirm that there are current plans to develop long-stay forensic services. Many country's experts commented that more investment and focus is needed on improving and developing regular inpatient forensic care as well as outpatient care before discussions regarding long-stay services can be considered (Finland, Latvia, Lithuania). Anticipated barriers to setting-up potential future long-stay forensic services included institutional barriers, lack of financing and public attitude towards MDOs.

'Money, money, money and attitude towards offenders in society' (Belgium)

'[H]ealthcare professionals are not pushing the issue forward and again this isolation keeps them on the level that they have been working ten years ago' (Serbia)

\section{Ethical Issues}

Amongst the countries, attitudes to long-stay were mixed and experts raised some pertinent ethical issues regarding treatment philosophies and lengths of stay. The expert in Belgium specifically emphasised that ethical issues regarding coercion and mandatory treatment, as well as the right to have a sexual life, were important factors, particularly when patients are detained for prolonged periods of time. The expert in Serbia identified general institutional ethical considerations, including 'professional isolation' of forensic psychiatrists:

'... [P]rofessionally, they are isolated; meaning that they don't receive on a regular basis, let's say training on issues of health and human rights and ethics' (Serbia). 


\section{Forensic long-stay in Europe}

Not all country experts identified specific ethical issues concerning the development of longstay services and anticipated populations:

'... I think you have to have a good structure for arguing why you need to continually detain somebody and as long as you've got that clear structure... I don't think the ethical issues arise, to be frank' (England).

Experts in Poland and Portugal acknowledged the conflict between the personal freedom and autonomy of patients as well as safety of the public, particularly when patients lack insight into their mental disorder:

'...[T]o what extent shall these patients be treated as general criminals and to [what] extent must they be regarded as someone who has some mental disorder?' (Portugal).

Experts in the Netherlands identified the negative association that emerged after the (initially positively perceived) development of long-stay services.

'... [W]hen you are [in long-stay] that's life-long detention in a very awkward situation where you will not be treated because in the [court] ruling it says when somebody's not treatable.... now we are fighting back a bit because our rates [demonstrate] that people are in fact leaving the system... but people don't understand it [or] take notice' (the Netherlands, Expert B).

Providing efficient, effective treatment, beneficial for improving mental health as well as risk reduction and achieving a higher quality of life for patients, is challenging in a forensic environment, in which restrictions are placed upon patients (Buchanan et al., 2011; Mason, 1999). It has been suggested that addressing quality of life for patients within a restrictive forensic psychiatric setting may have an important part to play in improving treatment 


\section{Forensic long-stay in Europe}

outcomes and lowering recidivism risks in the long-term (Nieuwenhuizen \& Nijman, 2009; Völlm, Bartlett, \& McDonald, 2016). These competing concerns were, unsurprisingly, recognised by all country experts.

\section{Discussion}

\section{Main Findings}

The purpose of this study was to explore existing long-stay forensic mental health service provisions, as well as identify characteristics in potential long-stay populations and services offered in the included 18 European countries. Each country offers some form of mental health care for MDOs either in prison, general psychiatric practice or in forensic settings. Representative experts from eight countries stated that specific services are available for long-stay forensic inpatients, either in a separate hospital or specific treatment wards.

It is clear from the information we gathered that what constitutes a 'long-stay' varies widely between countries, as do treatment philosophies, service provisions and attitudes towards potential long-stay services. What is not clear from the information gathered is whether longstays are due to an inappropriateness of treatment interventions in various jurisdictions, or whether the interaction with service provision promotes recovery or rehabilitation of patients. In order to answer these questions, all countries would need to make seismic efforts to contribute towards establishing an evidence-base for appropriate treatment and outcome measures for particular patient populations, including personality disorder and sex offenders (which at present is limited - see Khalifa et al., 2010; Khan et al., 2015), as well as improve record-keeping and progress of individual patients. The Netherlands and Germany are highlighted as providing the most well established specific long-stay services. These two countries are identified as having progressed the furthest in the development of long-stay 


\section{Forensic long-stay in Europe}

services, but are still in the process of justifying their need in terms of demonstrating that it is possible to discharge patients - not all are lost to long-stay.

The remaining countries that currently provide long-stay services (or 'slow-stream' or similar terms used in England and Ireland) do so in special wards or treatment units, with the aim of improving quality of life and the promotion of wellbeing forming the fundamental treatment philosophy when attempts to engage in traditional or standard models of treatment have failed. Of the countries that do not currently offer specific long-stay services, five expressed a need to initiate the development of such services for their longer-stay populations. Importantly, the label 'long-term' and any potential specific long-stay services carry a political and ideological concern, as identified by some of the countries' experts.

For countries that are in the process of developing long-term forensic mental health services, international dialogue can serve to be invaluable by learning from other countries, particularly those with which we share a common bond in unity under the EU or through our understanding and promotion of international human rights. It is clear that long-stay patients are a reality in many of this study's included countries, demonstrating that care is happening either formally (for countries that currently provide long-stay services) or informally (for those who do not). The perceived importance of developing designated forensic long-stay services rests in recognising the proportion of patients who do not necessarily respond well to standard treatment and who are still deemed to present a risk to society. The balance seemingly to be had is differentiating between the 'long-stayers' and those with shorter stays who are more 'able' to move through services. Indeed, not all countries expressed a need for separate services for 'long-stayers' and 'non-long-stayers'. The Netherlands was the only country included that provided a clear process of assessing patients suitable for transfer to a 


\section{Forensic long-stay in Europe}

long-stay facility (TBS), while other countries markedly differed. Other countries also offering some type of long-stay services were not necessarily guided by specific national laws or policies, meaning that the design of such services is left to individual units, resulting in inconsistencies. This is a potential conflict with the CRPD, notably in terms of 'reasonable accommodation', in which persons who are deprived of their liberty through any process should be able to exercise, on an equal basis with others, human rights and fundamental freedoms. With services so varied in definition and delivery between countries (all signatories to the convention) this leads to lack of clarity as to what would constitute 'reasonable accommodation' for the purposes of the CRPD.

As individual country experts indicated, common characteristics associated with long-stay included treatment non-response, chronic mental disorder, and dangerous or violent behaviour. Long-stay services emerged in part as a response to this chronicity and treatmentresistance to focus less on risk reduction and more towards improving quality of life, where standard services are not perceived to suitably cater for the needs of long-stay patients, nor provide positive treatment response. An anticipated benefit of long-stay services, particularly in the Netherlands, was also to reduce costs of lengthy stays in low-volume, resource intensive inpatient forensic services; however, country experts cast doubt onto these expectations, with an aging population requiring much higher, costly levels of care and support.

With a move towards longer periods of care, it is understandable that concerns are raised regarding potential (re)institutionalisation of patients. In conflict with this concern is the political and societal ideology of risk-based containment integral to modern day European society (Priebe et al., 2005). The responses of experts involved in this study largely confirm 


\section{Forensic long-stay in Europe}

this conflict, with no current answers on how to overcome the complexities of balancing patients' rights whilst ensuring public safety.

\section{Study Limitations}

To our knowledge, this is the first exploratory study that has compared the availability of longstay services from 18 countries within Europe. We were able to interview individual experts with extensive experience, training and knowledge who could offer authoritative observations regarding service use, implementation, current provision and future prospects of long-term forensic care in their countries. This study also builds upon the existing (now relatively dated) comparative work (Salize \& Dressing 2005; Salize, Dressing, \& Kief 2007; Salize, Dressing, \& Peitz, 2002). This study contributes towards this developing area of longstay service provision, with both questionnaires and follow-up interviews adopted in methods. Further, the addition of two former Soviet Socialist Republics (Lithuania and Latvia) and four former Yugoslavia Republics (Croatia, Macedonia, Serbia and Slovenia) provides for more inclusive discussion, and sheds light on service provisions in countries with still a relatively young history under modern governments. In acknowledging these strengths, weaknesses must also be considered.

Firstly, all experts interviewed were able to provide insight into their local practices, which may not necessarily be representative of their entire country. In the same vein, interview data rely largely on the observations and impressions of individual experts, rather than empirical data on LoS, recidivism and risk, and differences in treatment approaches. Further research should be directed towards these areas, as well as gauging the use of evidence-based treatment practices. 


\section{Forensic long-stay in Europe}

Secondly, each country operates under differing governments with widely varying populations and markedly different histories (particularly in the provision and practice of psychiatry and the availability of experts in the sub-speciality of forensic psychiatry) making comparison between countries difficult, with heterogeneity of concepts, legislation and practice greatly expected. This heterogeneity, however, serves as a reminder of the pluralism and diversity within Europe.

Thirdly, all questionnaires and interviews were conducted in the English language, which presents a challenge in fairly representing and interpreting participants' responses for nonnative English speakers (Van Nes, Abma, Jonsson, \& Deeg 2010). Context-bounded concepts may also pose an obstacle to 'effective and meaningful international comparison' (Hantrais, 2009). However, we sought to understand the interpreted experience of the participants and represent their opinions and responses in a meaningful way within the appropriate contexts. We also sent participants their transcript to read and amend as necessary to ensure we captured the correct meaning.

Also, not all European countries were included in this study; therefore results are not generalizable or representative across Europe.

Finally, all participants interviewed were psychiatrists, academics and other highly trained specialists in the field of psychiatry or forensic psychiatry; however, patient voices are missing from this discussion. In particular, patient perspectives on quality of life from those currently within long-stay services would be invaluable in order to paint a more holistic picture.

\section{Conclusions}




\section{Forensic long-stay in Europe}

Our findings have important implications for policy and service developments. Efforts are needed to identify a definition of what constitutes 'long-stay'. Without a clear definition, whether based on actual years of detention or a measure relative to the average length of stay, it is not possible to develop specific policies for this patient group. Given the specific needs to long-stay patients such specific policies are necessary, whether or not they include separate service provision.

Further research should encapsulate the patient perspective of long-stay service provisions, as well as performing longitudinal outcome and economic analyses of existing long-stay forensic service provisions. Such observational research will inform us about how long-stay services are currently performing, their associated costs, and the attitudes of their patient populations and allow the development of best practise recommendations for this group.

\section{Acknowledgements}

The authors would like to thank all COST members interviewed for their participation in this research.

\section{Conflict of interests}

The authors declare that they have no conflicts of interest concerning this research.

References

Alderman, N. (2001). Management of challenging behaviour in Wood, R., \& McMillan, T., (eds.), Neurobehavioural disability and social handicap following traumatic brain injury (pp. 175-207) Hove: Psychology Press. 


\section{Forensic long-stay in Europe}

Andreasson, H., Nyman, M., Krona, H., Meyer, L., Anckarsäter, H., Nilsson, T., Hofvander, B. (2014). Predictors of length of stay in forensic psychiatry: the influence of perceived risk of violence, International Journal of Law and Psychiatry, 37(6), 635-42, doi: 10.1016/j.ijlp.2014.02.038.

Bagarić, D., Živković, M., Curković, M., Radić, K., \& Brečić, P. (2014). Informed consent in psychiatric research - concepts and challenges. Psychiatria Danubina, 26(3): 271-276

Baldwin, L.J., Menditto, A.A., Beck, N.C., \& Smith, S.M. (1992). Factors influencing length of hospitalization for NGRI acquittees in a maximum security facility. Journal of Psychiatry and Law, 20, 257-269.

Barbui, C., \& Saraceno, B. (2015). Closing forensic psychiatric hospitals in Italy: a new revolution begins? The British Journal of Psychiatry, 206(6), 445-446, doi: 10.1192/bjp.bp.114.153817.

Boyd-Caine, T. (2012). Protecting the public? Detention and release of mentally disordered offenders. Routledge: Oxford.

Brown, K., \& Fahy, T. (2009). Medium secure units: pathways of care and time to discharge over a four-year period in South London. Journal of Forensic Psychiatry and Psychology, 20, 268-277, doi: $10.1080 / 14789940802327291$.

Buchanan, A., \& Grounds, A. (2011). Forensic psychiatry and public protection. The British Journal of Psychiatry, 198: 420-423, doi: 10.1192/bjp.bp.111.095471.

Colwell, L.H., \& Colwell, K. (2011). Assessing feigned cognitive impairment in defendants hospitalized for competency restoration: further validation of the TOMI, presented at the American Psychology Law Society $4^{\text {th }}$ International Congress of Psychology and Law 2011, Miami, doi: $10.1080 / 15228932.2011 .562804$. 


\section{Forensic long-stay in Europe}

Council of Europe, European Convention for the Protection of Human Rights and Fundamental Freedoms, as amended by Protocols Nos. 11 and 14, 4 November 1950, ETS 5. Retrieved from: http://www.refworld.org/docid/3ae6b3b04.html.

Council of Europe, European Convention for the Prevention of Torture and Inhuman or Degrading Treatment or Punishment, 26 November 1987, ETS 126. Retrieved from: http://www.refworld.org/docid/3ae6b36314.html.

Dell, S., Robertson, G., \& Parker, E. (1987). Detention in Broadmoor: factors in length of stay. British Journal of Psychiatry, 150, 824-827, doi: 10.1192/bjp.150.6.824.

Edwards, J., Steed, P. \& Murray, K. (2002). Clinical and forensic outcome 2 years and 5 years after admission to a medium secure unit. The Journal of Forensic Psychiatry, 13(1): 68-87, doi: 10.1080/09585180210123294.

Fereday, J. (2006). Demonstrating rigour using thematic analysis: a hybrid approach of inductive and deductive coding and theme development. International Journal of Qualitative Methods, 5(1), 80-92, doi: $10.1177 / 160940690600500107$.

Fisher, W., Barreira, P., Geller, J., White, A., Lincoln, A., \& Sudders, M. (2001). Long-stay patients in state psychiatric hospitals at the end of the $20^{\text {th }}$ century. Psychiatric Services 52(8), 1051-1056, doi: 10.1176/appi.ps.52.8.1051

Giesler, M. (2012). Long-term forensic psychiatric care: Why? Who? How? presented at the International Association of Forensic Mental Health Services Annual Conference 2012, Miami.

Green, B. \& Baglioni, A. J. (1998). Length of stay, leave and re-offending by patients from a Queensland security patients hospital. Australian and New Zealand Journal of Psychiatry, 32(6): 839-847, doi: $10.3109 / 00048679809073874$.

Hantrais, L. (2009). International comparative research: theory, methods and practice, Palgrave Macmillan: New York. 


\section{Forensic long-stay in Europe}

Hodgins, S., Müller-Isberner, R., \& Allaire, J.F. (2006). Attempting to understand the increase in the numbers of forensic beds in Europe: a multi-site study of patients in forensic and general psychiatric services. International Journal of Forensic Mental Health, 5(2). 173-184, doi: 10.1080/14999013.2006.10471241.

Jacques, J., Spencer, S.J., \& Gilluley, P. (2010). Long-term care needs in male medium security. British Journal of Forensic Practice, 12, 37-44, doi: http://dx.doi.org/10.5042/bjfp.2010.0424

Jansman-Hart, E.M., Seto, M.C., Crocker, A.G., Nicholls, T.L., \& Cote, G. (2011). International trends in demand for forensic mental health services. International Journal of Forensic Mental Health, 10, 326-336, doi: 10.1080/14999013.2011.625591.

Joint Commissioning Panel for Mental Health (2013). Guidance for commissioners of forensic mental health services, Centre for Mental Health, May 2013. Retrieved from: http://www.jcpmh.info/wp-content/uploads/icpmh-forensic-guide.pdf

Kennedy, J., Wilson, C., \& Cope, R. (1995). Long-stay patients in a regional secure unit. Journal of Forensic Psychiatry and Psychology, 6, 541-551, doi: 10.1080/09585189508410782.

Khalifa, N., Duggan, C., Stoffers, J., Huband, N., Völlm, B.A., Ferriter, M., Lieb, K. (2010). Pharmacological interventions for antisocial personality disorder. Cochrane Database of Systematic Reviews 2010, Issue 8. Art. No.: CD007667. DOI: 10.1002/14651858.CD007667.pub2.

Khan, O., Ferriter, M., Huband, N., Powney, M.J., Dennis, J.A., Duggan, C. (2015). Pharmacological interventions for those who have sexually offended or are at risk of offending. Cochrane Database of Systematic Reviews 2015, Issue 2. Art. No.: CD007989. DOI: 10.1002/14651858.CD007989.pub2. 


\section{Forensic long-stay in Europe}

Konrad, N., \& Völlm, B. (2010). Forensic Psychiatry in Helmchen, H., \& Sartorius, N. (eds.) Ethics in Psychiatry - European contributions (pp. 363-381) Heidelberg: Springer Verlag.

Large, M.M, Ryan, C.J., Singh, S.P., Paton, M.B., Nielssen, O.B. (2011). The predictive value of risk categorisation in schizophrenia. Harvard Review of Psychiatry, 19(1), 25-33, doi: 10.3109/10673229.2011.549770.

Law No. 36/98, 24 July 1998 (Portugal).

Long, C., Dickens, G., Sugarman, P., Craig, L., Mochty, U., \& Hollin, C. (2010). Tracking risk profiles and outcome in a medium secure service for women: Use of the HoNOS-secure. International Journal of Forensic Mental Health, 9, 215-225, doi: 10.1080/14999013.2010.517256.

Long, C.G., \& Dolley, O. (2012). Factors predictive of length of stay for women in medium secure settings. Journal of Psychiatric Mental Health Nursing, 19(10), 870-874, doi: 10.1111/j.13652850.2011.01866.x.

Mason, T. (1999). The psychiatric 'Supermax'?: long-term, high-security psychiatric services. International Journal of Law and Psychiatry, 22(2), 155-166, doi: 10.1016/S0160-2527(98)00040-5.

McKenna, J. (1996). In-patient characteristics in a regional secure unit. Psychiatric Bulletin, 20, 264268, doi: 10.1192/pb. 20.5.264.

Melzer, D., Tom, B.D.M., \& Brugha, T. et al. (2004). Access to medium secure psychiatric care in England and Wales: The clinical needs of assessed patients. Journal of Forensic Psychiatry and Psychology 15, 50-65, doi: 10.1080/14789940410001661856.

Mental Health Act 1983 (England \& Wales) c20. Retrieved from: <http://www.legislation.gov.uk/ukpga/1983/20/contents >

Mental Health Act 2007 (England \& Wales) c12. Retrieved from: <http://www.legislation.gov.uk/ukpga/2007/12/contents [accessed August 2015]

Mental Health Act 2001 (Republic of Ireland) no.25. Retrieved from: <http://www.irishstatutebook.ie/2001/en/act/pub/0025/> 


\section{Forensic long-stay in Europe}

Mental Health Care of the Republic of Lithuania 1997 (Lithuania) no.5. Retrieved from: <http://www.vpsc.lt/vpsc anglu/Law\%20on\%20Mental\%20Health\%20care.htm>

Mental Health Act 1990 (Finland) no. 1116/1990. Retrieved from:

<https://www.finlex.fi/en/laki/kaannokset/1990/en19901116.pdf>

Mental Health Act 2008 (Slovenia) Official Gazette of the Republic of Slovenia, no.77/2008.

Mental Health Act 2000 (Spain).

Mullen, P.E. (2000). Forensic mental health. The British Journal of Psychiatry, 176, 307-311, doi: 10.1192/bjp.176.4.307.

Nagtegaal, M.H., van der Host, R.P., \& Schonberger, H.J.M. (2011). Length of stay in forensic psychiatric hospitals: numbers and possible explanations. The Hague: Boom Juridische Uitgevers.

Nieuwenhuizen, C.V., Nijman, H. (2009). Quality of life of forensic psychiatric inpatients. International Journal of Forensic Mental Health, 8,(1), 9-15, doi: 10.1080/14999010903014671.

NVivo; QSR International Pty Ltd. Version 10.0.638.0 SP6, 1999-2014.

O'Neill, C., Haffernan, P., Goggins, R., Corcoran, C., Linehan, S., Duffy, D., O'Neill, H., Smith, C., \& Kennedy, H. (2003). Long-stay forensic psychiatric inpatients in the Republic of Ireland: aggregated needs assessment. Irish Journal of Psychological Medicine, 20(4), 119-125, doi: http://dx.doi.org/10.1017/\$0790966700007916.

Priebe, S., Badesconyi, A., Fioritti, A., Hansson, L., Kilian, R., Torres-Gonzales, F., \& Wiersma, D.R. (2005). Reinstitutionalisation in mental health care: comparison of data on service provision from six European countries. British Medical Journal, 330, 123-126, doi: 10.1136/bmj.38296.611215.AE.

Priebe, S., Frottier, P., Gaddini, A., Kilian, R., Lauber, C., Martinez-Leal, R., \& Wright, D. (2008). Mental health care institutions in nine European countries. Psychiatric Services, 59, 570-573, doi: 10.1176/appi.ps.59.5.570.

Protection of Persons with Mental Disorders 2013 (Serbia). 


\section{Forensic long-stay in Europe}

Protection of Persons with Mental Disorders 2015 (Croatia).

Rutherford, M., \& Duggan, S. (2007). Forensic Mental Health Services: Facts and figures on current provision, The Sainsbury Centre for Mental Health.

Salize, H.J., Dressing, H., \& Peitz, M. (2002). Compulsory admission and involuntary treatment of mentally ill patients: legislation and practice in EU Member States. European Commission Health and Consumers Protection Directorate-General, Mannheim, Germany, May 152002.

Salize, H.J., \& Dressing, H. (2005). Placement and treatment of mentally ill offenders: legislation and practice in EU Member States, European Commission - Health and Consumer Protection Directorate-General, Mannheim, Germany, February 152005.

Salize, H.J., Dressing, H., \& Kief, C. (2007). Mentally disordered persons in European prison systems needs, programmes and outcomes (EUPRIS) European Commission - The SANCO Directorate General, Mannheim, Germany, October 312007.

Schel, S.H., Bouman, Y.H., \& Bulten, B.H. (2015). Quality of life in long-term forensic psychiatric care: comparison of self-report and proxy assessments. Archives of Psychiatric Nursing, 29(3), $162-$ 167, doi: 10.1016/j.apnu.2015.01.004.

Shah, A., Waldron, G., Boast, N., Coid, J.W., \& Ullrich, S. (2011). Factors associated with length of admission at a medium secure forensic psychiatric unit. Journal of Forensic Psychiatry \& Psychology, 22(4), 496-512, doi: 10.1080/14789949.2011.594902.

Sharma, A., Dunn, W., O'Toole, C., Kennedy, H.G. (2015 The virtual institution: cross-sectional length of stay in general adult and forensic psychiatry beds. International Journal of Mental Health Systems, 9, 25. doi: 10.1186/s13033-015-0017-7. 


\section{Forensic long-stay in Europe}

Shaw, J., Davies, J., \& Morey, H. (2001). An assessment of the security, dependency and treatment needs of all patients in secure services in a UK health region. Journal of Forensic Psychiatry and Psychology, 12, 610-637, doi: 10.1080/09585180127380.

Sugarman, P., \& Oakley, C. (2012). The evolution of secure and forensic care. The Journal of Forensic Psychiatry and Psychology, 23(3), 279-84, doi: 10.1080/14789949.2012.692094.

United Nations General Assembly (2006). Convention on the Rights of Persons with Disabilities, 13 December 2006, A/RES/61/106, Annex I. Retrieved from: <http://www.refworld.org/docid/4680cd212.html>

United Nations (2015). International Covenant on Civil and Political Rights, Human Rights Committee $113^{\text {th }}$ session (summary record of the $3146^{\text {th }}$ meeting) Third periodic report of Croatia, $23^{\text {rd }}$ March 2015, CCPR/C/SR.3146. Retrieved from: <http://www.ccprcentre.org/doc/2015/04/SR3146-En1.pdf>

Van Nes, F., Abma, T., Jonsson, H., \& Deeg, D. (2010). Language differences in qualitative research: is meaning lost in translation? European Journal of Aging, 7(4), 313-316, doi: 10.1007/s10433010-0168-y.

Völlm, B. (2015). Characteristics and needs of long-stay patients in high and medium secure forensic psychiatric care: Implications for service organisation, presented at International Association of Forensic Mental Health Services Annual Conference 2015, Manchester.

Vorstenbosch, E.C.W., Bouman, Y.H.A, Braun, P.C., Bulten, E.B.H. (2014). Psychometric properties of the forensic inpatient quality of life questionnaire: quality of life assessment for long-term forensic psychiatric care. Health Psychology and Behavioural Medicine, 1(2) 335-48, doi: $10.1080 / 21642850.2014 .894890$. 


\section{Forensic long-stay in Europe}

Walker, J., Craissati, J., Batson, S., Amos, T., \& Knowles, P. (2012). How to get better value for money from psychiatric care units. Health Service Journal. Retrieved from: $<$ http://www.hsj.co.uk/sectors/commissioning/how-to-get-better-value-for-money-frompsychiatric-care-units/5041168.fullarticle>

Wheatley, M., Waine, J., Spence, K., \& Hollin, C. (2004). Characteristics of 80 adolescents referred for secure inpatient care. Clinical Psychology \& Psychotherapy, 11, 83-89, doi: 10.1002/cpp.398.

World Health Organisation (WHO) (2005). Mental Health Atlas 2005, World Health Organisation, Geneva. Retrieved from: <http://www.who.int/mental health/evidence/mhatlas05/en/>

Yorston, G. (1999). Aged and dangerous. Old-age forensic psychiatry. British Journal of Psychiatry, 174, 193-195, doi: 10.1192/bjp.174.3.193.

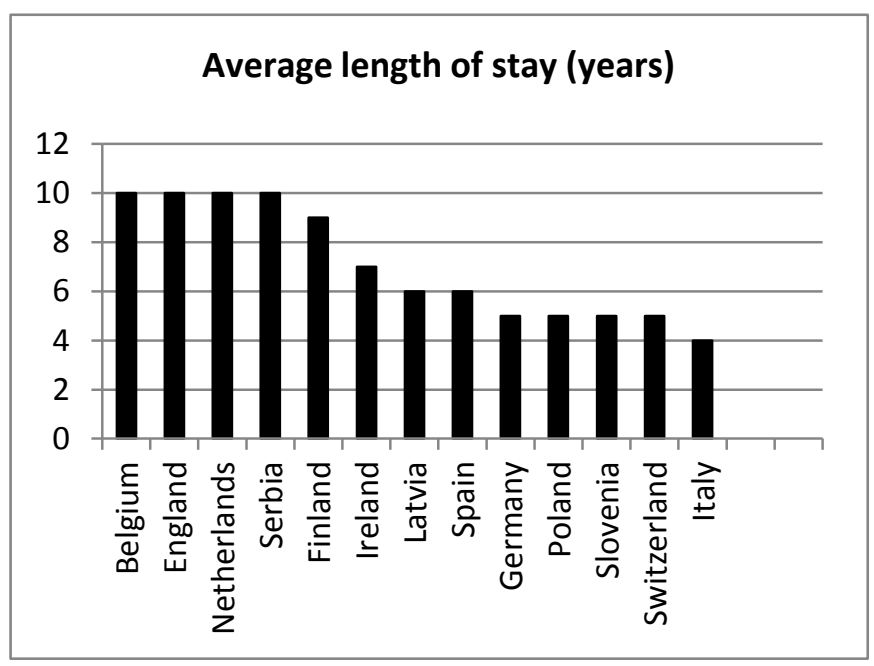

Figure 1: Expert participant observation of average length of stay in forensic inpatients at medium and high secure levels (not defined) and long-stay services (Spain, Netherlands) 


\section{Forensic long-stay in Europe}

\section{Table 1}

\begin{tabular}{|c|c|c|c|c|c|}
\hline Country & $\begin{array}{l}\text { Type of state \& } \\
\text { population }^{6}\end{array}$ & Facilities $^{7}$ & $\begin{array}{l}\text { Diversion from prison } \\
\text { to hospital possible } \\
\text { (post-sentencing) }\end{array}$ & $\begin{array}{l}\text { Hospital security levels } \\
\text { (approx. number of } \\
\text { beds) }\end{array}$ & Governance and funding \\
\hline Belgium & $\begin{array}{l}\text { Federal } \\
11 \text { million }\end{array}$ & $\begin{array}{l}\text { - } 3 \text { social defence establishments } \\
\text { - } 2 \text { high secure hospitals } \\
\text { - } 3 \text { medium secure forensic } \\
\text { wards } \\
\text { - Basic prison psychiatric } \\
\text { services }\end{array}$ & Yes & $\begin{array}{l}\text { High }(370) \\
\text { Medium (150) } \\
\text { Low }\end{array}$ & $\begin{array}{l}\text { - Joint Federal Ministry of } \\
\text { Justice and Federal Ministry of } \\
\text { Public Health (forensic } \\
\text { services) } \\
\text { - Federal Ministry of Justice } \\
\text { (prison services) } \\
\text { - Wallonia: joint Minister of } \\
\text { Social Welfare and Ministry of } \\
\text { Justice } \\
\text { - Paifve: largely subsidised by } \\
\text { Ministry of Justice }\end{array}$ \\
\hline Croatia & $\begin{array}{l}\text { Unitary } \\
4.5 \text { million }\end{array}$ & $\begin{array}{l}\text { - Forensic psychiatric } \\
\text { departments in } 4 \text { out of } 5 \\
\text { psychiatric hospitals } \\
\text { - } 1 \text { prison hospital } \\
\text { - Prison psychiatric services for } \\
\text { substance misuse } \\
\end{array}$ & $\begin{array}{l}\text { No } \\
\text { (Sent to prison } \\
\text { hospital) }\end{array}$ & $\begin{array}{l}\text { High } \\
\text { Medium } \\
\text { Low }\end{array}$ & $\begin{array}{l}\text { - Ministry of Health (forensic } \\
\text { services) } \\
\text { - Federal Ministry of Justice } \\
\text { (prison services) }\end{array}$ \\
\hline England & $\begin{array}{l}\text { Unitary (UK), } \\
\text { devolved } \\
\text { healthcare } \\
\text { provision } \\
53 \text { million }^{8}\end{array}$ & $\begin{array}{l}\text { - } 3 \text { high secure forensic hospitals } \\
\text { - Approx. } 60 \text { medium secure } \\
\text { forensic hospitals } \\
\text { - Low secure forensic hospitals } \\
\text { - Prison psychiatric services } \\
\text { (wards and prison 'in-reach' } \\
\text { teams) }\end{array}$ & Yes & $\begin{array}{l}\text { High }(800) \\
\text { Medium }(3-4000) \\
\text { Low }(3-4000)\end{array}$ & $\begin{array}{l}\text { - Joint Ministry of Justice and } \\
\text { Department of Health } \\
\text { (forensic and prison services) } \\
\text { - Private/ independent } \\
\text { providers for up to } 60 \% \text { of } \\
\text { medium and low secure } \\
\text { services }\end{array}$ \\
\hline Finland & $\begin{array}{l}\text { Federate } \\
5 \text { million }\end{array}$ & $\begin{array}{l}\text { - } 2 \text { state hospitals } \\
\text { - } 3 \text { university hospital wards }\end{array}$ & Yes & $\begin{array}{l}\text { High } \\
\text { Medium } \\
\text { Low }\end{array}$ & $\begin{array}{l}\text { - Ministry of Social Affairs and } \\
\text { Health (forensic services) }\end{array}$ \\
\hline
\end{tabular}

${ }^{6}$ All country population estimates from The World Bank (2013) http://data.worldbank.org/indicator/SP.POP.TOTL

${ }^{7}$ Data complemented by reference to Salize and Dressing 2005 and the World Health Organisation mental health atlas (WHO 2005)

${ }^{8}$ England population estimates from Office of National Statistics, annual mid-year population estimates (2013) http://www.ons.gov.uk/ons/dcp171778_367167.pdf 
Forensic long-stay in Europe

\begin{tabular}{|c|c|c|c|c|c|}
\hline & & $\begin{array}{l}\text { - Basic prison psychiatric } \\
\text { services }\end{array}$ & & $\begin{array}{l}\text { Open-ward } \\
\text { (470 total) }\end{array}$ & 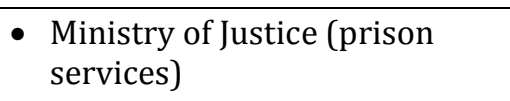 \\
\hline France & $\begin{array}{l}\text { Federate } \\
65 \text { million }\end{array}$ & $\begin{array}{l}\text { - Regular psychiatric hospitals } \\
\text { - } 2 \text { high secure hospitals } \\
\text { - } 2 \text { prison psychiatric units } \\
\text { - Minimal prison psychiatric } \\
\text { services (for MDOs who accept } \\
\text { treatment) }\end{array}$ & Yes & $\begin{array}{l}\text { Maximum } \\
\text { High }\end{array}$ & $\begin{array}{l}\text { Ministry of Health and Social } \\
\text { Affairs (forensic services and } \\
\text { two prison psychiatric units) }\end{array}$ \\
\hline Germany & $\begin{array}{l}\text { Federal } \\
80 \text { million }\end{array}$ & $\begin{array}{l}\text { - Approx. } 65 \text { high to open-ward } \\
\text { forensic psychiatric hospitals } \\
\text { (50-400 patients in each) } \\
\text { - Forensic wards within general } \\
\text { psychiatric hospitals } \\
\text { - Prison psychiatric wards }\end{array}$ & No & $\begin{array}{l}\text { Each hospital offers } \\
\text { high, medium and low } \\
\text { secure services (7000) }\end{array}$ & $\begin{array}{l}\text { - Federal Ministry of Health } \\
\text { (forensic services) } \\
\text { - Federal Ministry of Justice } \\
\text { (prison services) }\end{array}$ \\
\hline Rep. Ireland & $\begin{array}{l}\text { Unitary } \\
4 \text { million }\end{array}$ & $\begin{array}{l}\text { - } 1 \text { forensic hospital (Dublin) } \\
\text { Prison psychiatric services } \\
\text { (wards and prison 'in-reach' } \\
\text { teams) }\end{array}$ & Yes & $\begin{array}{l}\text { High } \\
\text { Medium } \\
\text { Low } \\
\text { (each provided in the } 1 \\
\text { forensic hospital) } \\
\text { (94 total) }\end{array}$ & $\begin{array}{l}\text { - Department of Health } \\
\text { (forensic and prison services) }\end{array}$ \\
\hline Italy & $\begin{array}{l}\text { Devolved } \\
60 \text { million }\end{array}$ & $\begin{array}{l}\text { - } 6 \text { forensic hospitals }{ }^{9} \\
\text { - Prison psychiatric services }\end{array}$ & No & $\begin{array}{l}\text { High } \\
\text { Medium } \\
\text { Low }\end{array}$ & $\begin{array}{l}\text { - Ministry of Health (1 forensic } \\
\text { psychiatric hospital and } \\
\text { prison services) } \\
\text { - Ministry of Justice (majority of } \\
\text { forensic psychiatric hospitals) }\end{array}$ \\
\hline Latvia & $\begin{array}{l}\text { Unitary } \\
2 \text { million }\end{array}$ & $\begin{array}{l}\text { - } 1 \text { secure forensic unit (Riga) } \\
\text { - Secure psychiatric clinics } \\
\text { - Prison psychiatric services }\end{array}$ & Yes & $\begin{array}{l}\text { High } \\
\text { Medium } \\
\text { Low } \\
\text { Open-ward }\end{array}$ & 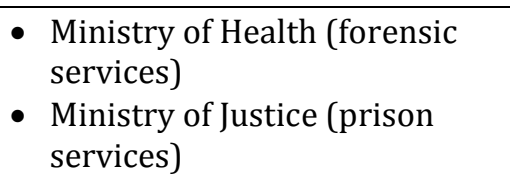 \\
\hline
\end{tabular}

${ }^{9}$ However, see Barbui \& Saraceno (2015), detailing new legislation that calls for downsizing and closure of these forensic hospitals. 


\section{Forensic long-stay in Europe}

\begin{tabular}{|c|c|c|c|c|c|}
\hline Lithuania & $\begin{array}{l}\text { Unitary } \\
3 \text { million }\end{array}$ & $\begin{array}{l}\text { - } 1 \text { secure forensic unit } \\
\text { (Rokiškis) } \\
\text { - Prison psychiatric services }\end{array}$ & No & $\begin{array}{l}\text { High } \\
\text { Medium } \\
\text { Low } \\
(320 \text { total) }\end{array}$ & $\begin{array}{l}\text { Ministry of Health (forensic } \\
\text { and prison services) }\end{array}$ \\
\hline $\begin{array}{l}\text { FYR } \\
\text { Macedonia }\end{array}$ & $\begin{array}{l}\text { Unitary } \\
2 \text { million }\end{array}$ & $\begin{array}{l}\text { - Forensic departments in } 2 \text { out } \\
\text { of } 3 \text { psychiatric hospitals } \\
\text { - Prison psychiatric ward (short } \\
\text { term treatment) }\end{array}$ & Yes & $\begin{array}{l}\text { High } \\
\text { Medium } \\
\text { Low }\end{array}$ & $\begin{array}{l}\text { - } \text { Ministry of Health (forensic } \\
\text { services) } \\
\text { - Ministry of Justice (prison } \\
\text { services) }\end{array}$ \\
\hline Netherlands & $\begin{array}{l}\text { Federate } \\
16 \text { million }\end{array}$ & $\begin{array}{l}\text { - Forensic Psychiatric Clinics } \\
\text { (TBS), including long stay TBS } \\
\text { - Forensic Psychiatric Units } \\
\text { (FPA) within general } \\
\text { psychiatric hospitals } \\
\text { - Prison psychiatric services } \\
\text { (PPCs); } 5 \text { Penitentiary } \\
\text { Psychiatric Centres } \\
\text { - } 1 \text { prison Forensic Observation } \\
\text { Unit (FOBA) }\end{array}$ & No & $\begin{array}{l}\text { High } \\
\text { Medium } \\
\text { Low } \\
\text { TBS (1867) } \\
\text { FOBA (66) }\end{array}$ & $\begin{array}{l}\text { Ministry of Safety and Justice } \\
\text { (forensic services; some } \\
\text { private) }\end{array}$ \\
\hline Poland & $\begin{array}{l}\text { Unitary } \\
38 \text { million }\end{array}$ & $\begin{array}{l}\text { - } 3 \text { high secure forensic hospitals } \\
\text { - } 17 \text { medium secure forensic } \\
\text { hospitals } \\
\text { - } 22 \text { low secure forensic } \\
\text { hospitals } \\
\text { - Prison psychiatric services }\end{array}$ & Yes & $\begin{array}{l}\text { High (193) } \\
\text { Medium (827) } \\
\text { Low (1495) }\end{array}$ & $\begin{array}{l}\text { - Joint Ministry of Health and } \\
\text { Ministry of Justice (forensic } \\
\text { and prison services) }\end{array}$ \\
\hline Portugal & $\begin{array}{l}\text { Unitary } \\
10 \text { million }\end{array}$ & $\begin{array}{l}\text { - } 2 \text { high secure forensic hospitals } \\
\text { - } 7 \text { general psychiatric hospitals } \\
\text { - } 1 \text { special prison hospital } \\
\text { (medium secure) } \\
\text { - Prison psychiatric services }\end{array}$ & Yes & $\begin{array}{l}\text { High } \\
\text { Medium } \\
\text { Low }\end{array}$ & $\begin{array}{l}\text { Ministry of Justice (forensic } \\
\text { services) } \\
\text { - Private/ independent } \\
\text { providers of prison psychiatric } \\
\text { services }\end{array}$ \\
\hline
\end{tabular}


Forensic long-stay in Europe

\begin{tabular}{|c|c|c|c|c|c|}
\hline Serbia & $\begin{array}{l}\text { Unitary } \\
7 \text { million }\end{array}$ & $\begin{array}{l}\text { - Closed forensic psychiatric } \\
\text { wards in } 2 \text { of } 5 \text { general } \\
\text { psychiatric hospitals } \\
\text { - Special prison hospital } \\
\text { - Prison psychiatric services }\end{array}$ & $\begin{array}{c}\text { No } \\
\text { (Sent to prison } \\
\text { hospital) }\end{array}$ & $\begin{array}{l}\text { High } \\
\text { Medium } \\
\text { Low }\end{array}$ & $\begin{array}{l}\text { Ministry of Health (forensic } \\
\text { departments or wards in } \\
\text { general psychiatric hospitals) } \\
\text { - Ministry of Justice (prison } \\
\text { hospital and services) }\end{array}$ \\
\hline Slovenia & $\begin{array}{l}\text { Unitary } \\
2 \text { million }\end{array}$ & $\begin{array}{l}\text { - } 1 \text { forensic hospital } \\
\text { - Prison psychiatric services } \\
\text { (outpatient) }\end{array}$ & Yes & $\begin{array}{l}\text { High } \\
\text { Medium } \\
\text { Low }\end{array}$ & $\begin{array}{l}\text { - Joint Ministry of Health and } \\
\text { Ministry of Justice (forensic } \\
\text { and prison services) }\end{array}$ \\
\hline Spain $^{10}$ & $\begin{array}{l}\text { Devolved } \\
46 \text { million }\end{array}$ & $\begin{array}{l}\text { - } 3 \text { psychiatric penitentiary } \\
\text { hospitals ( } 2 \text { in Spain ( } 398 \\
\text { beds), } 4 \text { in Catalonia (154 } \\
\text { beds)) } \\
\text { - } 1 \text { hospital for pre-trial MDOs } \\
\text { (Barcelona) } \\
\text { - Prison psychiatric services }\end{array}$ & Yes & $\begin{array}{l}\text { High (603 total) } \\
\text { Medium } \\
\text { Low }\end{array}$ & $\begin{array}{l}\text { Joint Department of Health } \\
\text { and Ministry of Justice } \\
\text { (forensic and prison services) }\end{array}$ \\
\hline Switzerland & $\begin{array}{l}\text { Federal } \\
8 \text { million }\end{array}$ & $\begin{array}{l}\text { - } 7 \text { closed forensic psychiatric } \\
\text { hospitals } \\
\text { - } 22 \text { 'half-open' forensic } \\
\text { psychiatric hospitals } \\
\text { - Prison psychiatric services }\end{array}$ & Yes & $\begin{array}{l}\text { High } \\
\text { Medium } \\
\text { Low }\end{array}$ & $\begin{array}{l}\text { - Federal Office of Public } \\
\text { (forensic services) } \\
\text { - Federal Department of Justice } \\
\text { and Police (prison services) }\end{array}$ \\
\hline
\end{tabular}

${ }^{10}$ Forensic and penitentiary services and admission criteria differ between Catalonia and the rest of Spain, with services more heavily privatised in Catalonia. 


\section{Forensic long-stay in Europe}

\section{Table 2}

\begin{tabular}{|c|c|c|c|c|c|c|}
\hline Country & Included populations & $\begin{array}{c}\text { Excluded } \\
\text { populations }\end{array}$ & $\begin{array}{l}\text { Connection between } \\
\text { mental disorder and } \\
\text { crime required? }\end{array}$ & $\begin{array}{l}\text { Diminished/ absent } \\
\text { criminal responsibility } \\
\text { required? }\end{array}$ & $\begin{array}{l}\text { Decision to discharge from forensic } \\
\text { psychiatric hospital }\end{array}$ & $\begin{array}{l}\text { Fixed release } \\
\text { date from } \\
\text { forensic } \\
\text { psychiatric } \\
\text { hospital? }\end{array}$ \\
\hline Belgium & $\begin{array}{l}\text { - Psychotic disorders } \\
\text { - Personality disorder } \\
\text { - Cognitive disorders } \\
\text { - Learning disabilities } \\
\text { (LD) } \\
\text { - Substance misuse } \\
\text { (associated with other } \\
\text { mental disorder) } \\
\text { - Mood disorders (high } \\
\text { comorbidity) }\end{array}$ & - None & $\begin{array}{l}\text { No } \\
\text { (Yes - prior to } \\
\text { sentencing) }\end{array}$ & Yes & $\begin{array}{l}\text { Court (based on one or more expert } \\
\text { evaluations) }\end{array}$ & No \\
\hline Croatia & $\begin{array}{l}\text { - Psychotic disorders } \\
\text { - Personality disorder } \\
\text { - Cognitive disorders } \\
\text { - Learning disabilities } \\
\text { - Substance misuse }\end{array}$ & - None & Yes & Yes & $\begin{array}{l}\text { Court (based on one or more expert } \\
\text { evaluations (forensic psychiatrist/ } \\
\text { team of in complicated cases)) }\end{array}$ & (not specified) ${ }^{11}$ \\
\hline England & $\begin{array}{l}\text { - Psychotic disorders } \\
\text { - Personality disorder } \\
\text { - Cognitive disorders } \\
\text { - Learning disabilities } \\
\text { - Substance misuse } \\
\text { (associated with other } \\
\text { mental disorder) }\end{array}$ & $\begin{array}{l}\text { - None (though } \\
\text { individuals with } \\
\text { LD can only be } \\
\text { admitted if } \\
\text { associated with } \\
\text { 'abnormally } \\
\text { aggressive or } \\
\text { seriously }\end{array}$ & No & No & $\begin{array}{l}\text { Ministry of Justice, responsible } \\
\text { clinician (usually a consultant } \\
\text { psychiatrist), hospital managers, } \\
\text { Mental Health Review Tribunal } \\
\text { (depending on Section) }\end{array}$ & No \\
\hline
\end{tabular}

${ }^{11}$ Since the time of the present study, new legislation has been introduced in Croatia specifying that patients cannot remain in forensic settings for longer than what would have been their sentence for the same offence had they been healthy and sent to prison. 
Forensic long-stay in Europe

\begin{tabular}{|c|c|c|c|c|c|c|}
\hline & & $\begin{array}{l}\text { irresponsible } \\
\text { conduct' ) }\end{array}$ & & & & \\
\hline Finland & $\begin{array}{l}\text { - Psychotic disorders } \\
\text { - Personality disorder } \\
\text { (associated with other } \\
\text { mental disorder) } \\
\text { - Cognitive disorders } \\
\text { - Learning disabilities } \\
\text { (associated with other } \\
\text { mental disorder) } \\
\text { - Substance misuse } \\
\text { (associated with other } \\
\text { mental disorder) }\end{array}$ & $\begin{array}{l}\text { - None (severe LD } \\
\text { patients } \\
\text { primarily } \\
\text { treated } \\
\text { separately from } \\
\text { forensic } \\
\text { patients) }\end{array}$ & Yes & No & $\begin{array}{l}\text { Board of forensic psychiatry } \\
\text { operating under the Ministry of } \\
\text { Social Affairs and Health; } \\
\text { administrative courts }\end{array}$ & No \\
\hline France & (not specified) & - None & Yes & Yes & Court & No \\
\hline Germany & $\begin{array}{l}\text { - Psychotic disorders } \\
\text { - Personality disorder } \\
\text { - Cognitive disorders } \\
\text { - Learning disabilities } \\
\text { (medium-severe) } \\
\text { - Substance misuse } \\
\text { - Comorbidity }\end{array}$ & - None & Yes & Yes & Court & No \\
\hline $\begin{array}{l}\text { Rep. } \\
\text { Ireland }\end{array}$ & $\begin{array}{l}\text { - Psychotic disorders } \\
\text { - Personality disorder } \\
\text { (associated with other } \\
\text { mental disorder) } \\
\text { - Cognitive disorders } \\
\text { - Learning disabilities } \\
\text { - Substance misuse } \\
\text { (associated with other } \\
\text { mental disorder) } \\
\text { - Autistic spectrum } \\
\text { - Acquired brain injury }\end{array}$ & $\begin{array}{l}\text { - Personality } \\
\text { disorder (if sole } \\
\text { disorder) } \\
\text { - Substance } \\
\text { misuse (if sole } \\
\text { disorder) }\end{array}$ & No & No & $\begin{array}{l}\text { Treating consultant, clinical director, } \\
\text { Mental Health Review Board, court } \\
\text { (remanded) }\end{array}$ & No \\
\hline
\end{tabular}


Forensic long-stay in Europe

\begin{tabular}{|c|c|c|c|c|c|c|}
\hline Italy & $\begin{array}{l}\text { - Psychotic disorders } \\
\text { - Personality disorder } \\
\text { (associated with other } \\
\text { mental disorder) } \\
\text { - Cognitive disorders } \\
\text { (associated with other } \\
\text { mental disorder) } \\
\text { - Learning disabilities } \\
\text { - Substance misuse } \\
\text { (associated with other } \\
\text { mental disorder) }\end{array}$ & - None & Yes & Yes & $\begin{array}{l}\text { Court (magistrate) (Magistrato di } \\
\text { Sorveglianza or the Trial Judge who } \\
\text { applied the security measure) }\end{array}$ & $\mathrm{No}^{12}$ \\
\hline Latvia & $\begin{array}{l}\text { - Psychotic disorders } \\
\text { - Personality disorder } \\
\text { - Cognitive disorders } \\
\text { - Learning disabilities } \\
\text { - Substance misuse } \\
\text { (associated with other } \\
\text { mental disorder) }\end{array}$ & $\begin{array}{l}\text { - Psychotic } \\
\text { disturbance (if } \\
\text { patient able to } \\
\text { control criminal } \\
\text { action at time of } \\
\text { offence, then } \\
\text { prison) } \\
\text { - Personality } \\
\text { disorder, } \\
\text { cognitive } \\
\text { impairment, LD, } \\
\text { substance abuse } \\
\text { (if sole } \\
\text { disorder) }\end{array}$ & Yes & Yes & $\begin{array}{l}\text { Court: based on evaluation of } \\
\text { forensic psychiatrist }\end{array}$ & No \\
\hline Lithuania & $\begin{array}{l}\text { - Psychotic disorders } \\
\text { - Cognitive disorders } \\
\text { - Learning disabilities } \\
\text { - Substance misuse } \\
\text { (associated with other } \\
\text { mental disorder) }\end{array}$ & $\begin{array}{l}\text { - Personality } \\
\text { disorder, LD (if } \\
\text { sole disorder) }\end{array}$ & Yes & Yes & Court & No \\
\hline
\end{tabular}

${ }^{12}$ Since the time of the present study, new legislation has been introduced in Italy specifying that patients cannot remain in forensic settings for longer than what would have been their sentence for the same offence had they been healthy and sent to prison. 


\section{Forensic long-stay in Europe}

\begin{tabular}{|c|c|c|c|c|c|c|}
\hline $\begin{array}{l}\text { FYR } \\
\text { Macedonia }\end{array}$ & $\begin{array}{l}\text { - Psychotic disorders } \\
\text { - Cognitive disorders } \\
\text { - Learning disabilities } \\
\text { - Substance misuse } \\
\text { (associated with other } \\
\text { mental disorder) }\end{array}$ & $\begin{array}{l}\text { Personality } \\
\text { disorder, LD (if } \\
\text { sole disorder) }\end{array}$ & Yes & Yes & $\begin{array}{l}\text { Ministry of Justice after opinion of } \\
\text { forensic psychiatrist }\end{array}$ & - \\
\hline $\begin{array}{l}\text { Netherland } \\
\text { s }\end{array}$ & $\begin{array}{l}\text { - Psychotic disorders } \\
\text { - Personality disorder } \\
\text { - Cognitive disorders } \\
\text { - Learning disabilities } \\
\text { - Substance misuse } \\
\end{array}$ & - None & Yes & Yes & Court (guided by TBS clinic opinion) & No \\
\hline Poland & $\begin{array}{l}\text { - Psychotic disorders } \\
\text { - Personality disorder } \\
\text { - Cognitive disorders } \\
\text { - Learning disabilities } \\
\text { - Substance misuse } \\
\end{array}$ & - None & Yes & Yes & $\begin{array}{l}\text { Court (based on opinion of } \\
\text { psychiatrist) }\end{array}$ & No \\
\hline Portugal & $\begin{array}{l}\text { - Psychotic disorders } \\
\text { - Personality disorder } \\
\text { - Cognitive disorders } \\
\text { - Learning disabilities } \\
\text { - Others (where } \\
\text { associated with mental } \\
\text { disorder and related to } \\
\text { criminal behaviour) } \\
\text { - All of the above on } \\
\text { case-by-case basis }\end{array}$ & $\begin{array}{l}\text { - Substance } \\
\text { misuse }\end{array}$ & Yes & No & Court & $\mathrm{No}^{13}$ \\
\hline Serbia & $\begin{array}{l}\text { - Psychotic disorders } \\
\text { - Personality disorder } \\
\text { - Cognitive disorders } \\
\text { - Learning disabilities } \\
\text { - Substance misuse }\end{array}$ & - None & Yes & No & $\begin{array}{l}\text { Court (based on opinion of } \\
\text { psychiatrist and psychologist) }\end{array}$ & No \\
\hline
\end{tabular}

${ }^{13}$ For crimes punishable by imprisonment for less than eight years, length of stay in a forensic mental health service cannot exceed this time (however, in practice this sometimes happens). However, should dangerousness not be found to justify continued stay in a forensic mental health facility (as reviewed every two years), then the patient must be discharged. 
Forensic long-stay in Europe

\begin{tabular}{|c|c|c|c|c|c|c|}
\hline Slovenia & $\begin{array}{l}\text { - Psychotic disorders } \\
\text { - Personality disorder } \\
\text { - Cognitive disorders } \\
\text { - Learning disabilities } \\
\text { - Substance misuse }\end{array}$ & - None & No & No & $\begin{array}{l}\text { Court (based on opinion of } \\
\text { independent psychiatrist) }\end{array}$ & No \\
\hline Spain & $\begin{array}{l}\text { - Psychotic disorders } \\
\text { - Personality disorder } \\
\text { - Cognitive disorders } \\
\text { - Learning disabilities } \\
\text { - Substance misuse } \\
\text { (associated with other } \\
\text { mental disorder) }\end{array}$ & $\begin{array}{l}\text { - } \text { Personality } \\
\text { disorder (if no } \\
\text { diminished } \\
\text { responsibility) } \\
\text { - Substance abuse } \\
\text { (if sole } \\
\text { disorder) } \\
\text { - Anxiety } \\
\text { - Paraphilia } \\
\text { - ADHD }\end{array}$ & Yes & Yes & Court & - \\
\hline Switzerland & $\begin{array}{l}\text { - Psychotic disorders } \\
\text { - Personality disorder } \\
\text { - Cognitive disorders } \\
\text { - Learning disabilities } \\
\text { - Substance misuse } \\
\text { - Asperger's syndrome }\end{array}$ & $\begin{array}{l}\text { - Personality } \\
\text { disorder (if sole } \\
\text { disorder) } \\
\text { - Substance abuse } \\
\text { (if sole } \\
\text { disorder) }\end{array}$ & Yes & No & $\begin{array}{l}\text { Court (based on opinion of treating } \\
\text { clinician) }\end{array}$ & No \\
\hline
\end{tabular}


Forensic long-stay in Europe

Table 3 


\section{Forensic long-stay in Europe}

\begin{tabular}{|c|c|c|c|c|}
\hline Country & $\begin{array}{l}\text { Definition of long-stay (forensic psychiatric } \\
\text { inpatients) }\end{array}$ & Service provision & Included populations & Treatment philosophies \\
\hline England & $\begin{array}{l}\text { None agreed } \\
\text { (Term 'long-stay' avoided) }\end{array}$ & $\begin{array}{l}\text { - Some long-stay wards } \\
\text { ('enhanced rehabilitation' or } \\
\text { 'slow-stream') } \\
\text { - Private forensic sector } \\
\text { provision for patients 'with } \\
\text { little prospect of discharge' }\end{array}$ & $\begin{array}{l}\text { - 'Complex diagnosis of a psychotic } \\
\text { disorder, personality disorder and } \\
\text { - 'Trug and alcohol misuse' } \\
\text { - schizophrenia' } \\
\text { - High security level } \\
\text { - Assaultive behaviour } \\
\text { - Risk to public }\end{array}$ & $\begin{array}{l}\text { Greater focus on quality of } \\
\text { life } \\
\text { 'Low stimulus environments' } \\
\text { for treatment-resistant } \\
\text { patients } \\
\text { 'Recovery-focused' } \\
\text { Psychological and medical } \\
\text { treatment for patients with } \\
\text { complex diagnoses }\end{array}$ \\
\hline France & None agreed & - 1 high-secure unit (Paris) & - 'Violent patients' & [No available data] \\
\hline Germany & None agreed & $\begin{array}{l}\text { - Wards provided in forensic } \\
\text { hospitals (open to high- } \\
\text { secure hospital) } \\
\text { - Some forensic hospitals } \\
\text { specialising in the care of } \\
\text { long-term patients (in } \\
\text { Hessen) }\end{array}$ & $\begin{array}{l}\text { - Forensic patients 'in the service } \\
\text { - 'onger than average' } \\
\text { - 'Not dischargeable in the } \\
\text { - 'Toreseeable future' } \\
\text { - 'Therapeutic non-responders' } \\
\text { - patients' } \\
\text { - Psychopathy, chronic acute } \\
\text { schizophrenia, chronically violent }\end{array}$ & $\begin{array}{l}\text { Regular psychiatric and } \\
\text { medical treatment } \\
\text { Greater focus on wellbeing }\end{array}$ \\
\hline Rep. Ireland & $\begin{array}{l}\text { 1. In the forensic hospital for more than } 5 \text { years; } \\
\text { and } \\
\text { 2. A recovery pathway to a community place } \\
\text { cannot be foreseen in the next five years (not } \\
\text { including those returned to prison and those } \\
\text { frequently readmitted) }\end{array}$ & $\begin{array}{l}\text { - Additional units at high or } \\
\text { medium security } \\
\text { - Special ward for longer-term } \\
\text { low secure care ('slow- } \\
\text { stream') }\end{array}$ & $\begin{array}{l}\text { - 'Mentally ill prisoners, e.g. } \\
\text { mentally ill life prisoners who are } \\
\text { not currently in the hospital' } \\
\text { - 'Revolving door prisoner patients' } \\
\text { - Treatment resistant, multiple } \\
\text { comorbidities, continuing } \\
\text { challenging and dangerous } \\
\text { behaviour }\end{array}$ & $\begin{array}{l}\text { Greater focus on quality of } \\
\text { life } \\
\text { 'Stratified therapeutic } \\
\text { security' - five-tier security } \\
\text { system } \\
\text { Regular psychiatric and } \\
\text { medical treatment } \\
\text { (clozapine) } \\
\text { Behavioural programmes }\end{array}$ \\
\hline
\end{tabular}


Forensic long-stay in Europe 


\section{Forensic long-stay in Europe}

\section{Table 4}

\begin{tabular}{|c|c|c|c|c|c|}
\hline Country & $\begin{array}{l}\text { Formal definition of long- } \\
\text { stay }\end{array}$ & $\begin{array}{l}\text { Long-stay populations } \\
\text { (length of stay in years) }\end{array}$ & $\begin{array}{l}\text { Potential included populations/ diagnoses } \\
\text { or 'blockages' }\end{array}$ & $\begin{array}{l}\text { Need for long- } \\
\text { stay services? }\end{array}$ & $\begin{array}{c}\text { Current plans to develop } \\
\text { long-stay forensic } \\
\text { services? }\end{array}$ \\
\hline Belgium & No & 10 years & $\begin{array}{l}\text { Treatment/ therapy-resistant } \\
\text { Sex offenders presenting risk } \\
\text { Schizophrenia }\end{array}$ & Yes & No \\
\hline Finland & 3 months & 9 years & $\begin{array}{l}\text { Hebephrenic schizophrenia (ICD-10) } \\
\text { Non-engagement in treatment }\end{array}$ & Unsure & No \\
\hline Italy & No & 4 years & $\begin{array}{l}\text { Violent patients } \\
\text { Schizophrenia or psychosis } \\
\text { Substance abuse } \\
\text { Personality disorder } \\
\text { Anti-social behaviour }\end{array}$ & - & No \\
\hline Latvia & No & 6 years & $\begin{array}{l}\text { Chronic disorder } \\
\text { 'High level of disability' }\end{array}$ & Yes & No \\
\hline Lithuania & 6 months & - & Chronic patients & - & No \\
\hline $\begin{array}{l}\text { FYR } \\
\text { Macedonia }\end{array}$ & 1 year & - & - & - & - \\
\hline Poland & No & 5 years & $\begin{array}{l}\text { Treatment non-responders } \\
\text { Chronic mental disorder } \\
\text { Organic brain disease } \\
\text { Substance misuse } \\
\text { Sexual disorders } \\
\text { Intellectual disability }\end{array}$ & Unsure & No \\
\hline Serbia & No & 10 years & - & Yes & No \\
\hline Slovenia & No & 5 years & Danger to society & Yes & Yes \\
\hline Switzerland & No & 5 years & $\begin{array}{l}\text { Treatment non-responders } \\
\text { Severe personality disorder } \\
\text { Schizophrenia } \\
\text { Asperger's syndrome } \\
\text { Intellectual disability }\end{array}$ & Yes & No \\
\hline
\end{tabular}


Forensic long-stay in Europe 
Forensic long-stay in Europe

\section{References}

Alderman, N. (2001). Management of challenging behaviour in Wood, R., \& McMillan, T., (eds.), Neurobehavioural disability and social handicap following traumatic brain injury (pp. 175207) Hove: Psychology Press.

Andreasson, H., Nyman, M., Krona, H., Meyer, L., Anckarsäter, H., Nilsson, T., Hofvander, B. (2014). Predictors of length of stay in forensic psychiatry: the influence of perceived risk of violence, International Journal of Law and Psychiatry, 37(6), 635-42, doi: 10.1016/j.ijlp.2014.02.038.

Bagarić, D., Živković, M., Curković, M., Radić, K., \& Brečić, P. (2014). Informed consent in psychiatric research - concepts and challenges. Psychiatria Danubina, 26(3): 271-276

Baldwin, L.J., Menditto, A.A., Beck, N.C., \& Smith, S.M. (1992). Factors influencing length of hospitalization for NGRI acquittees in a maximum security facility. Journal of Psychiatry and Law, 20, 257-269.

Barbui, C., \& Saraceno, B. (2015). Closing forensic psychiatric hospitals in Italy: a new revolution begins? The British Journal of Psychiatry, 206(6), 445-446, doi: 10.1192/bjp.bp.114.153817.

Boyd-Caine, T. (2012). Protecting the public? Detention and release of mentally disordered offenders. Routledge: Oxford.

Brown, K., \& Fahy, T. (2009). Medium secure units: pathways of care and time to discharge over a four-year period in South London. Journal of Forensic Psychiatry and Psychology, 20, 268277, doi: 10.1080/14789940802327291.

Buchanan, A., \& Grounds, A. (2011). Forensic psychiatry and public protection. The British Journal of Psychiatry, 198: 420-423, doi: 10.1192/bjp.bp.111.095471.

Colwell, L.H., \& Colwell, K. (2011). Assessing feigned cognitive impairment in defendants hospitalized for competency restoration: further validation of the TOMI, presented at the American 